\title{
JENIS IKAN LAUT DALAM YANG TERTANGKAP DI PERAIRAN ZONA EKONOMI EKSKLUSIF INDONESIA SAMUDERA HINDIA
}

\author{
Suprapto') dan Mas Tri Djoko Sunarno²) \\ 1) Peneliti pada Balai Riset Perikanan Laut, Muara Baru-Jakarta \\ 2) Peneliti Pada Pusat Riset Perikanan Tangkap, Jakarta. \\ Teregistrasi I tanggal: 18 Desember 2007; Diterima setelah perbaikan tanggal: 5 Mei 2008; \\ Disetujui terbit tanggal: 24 Desember 2008
}

\begin{abstract}
ABSTRAK
Pada periode tahun 2004-2005, Pusat Riset Perikanan Tangkap (Badan Riset Kelautan dan Perikanan-Departemen Kelautan dan Perikanan) bekerjasama dengan pemerintah Jepang (Overseas Fishery Cooperation Foundation) telah melakukan pengkajian sumber daya ikan laut dalam di perairan zona ekonomi eksklusif Indonesia Samudera Hindia dengan menggunakan K.R. Baruna Jaya IV (1.219 GT). Kapal ini dilengkapi sarana alat tangkap jaring pukat dimodifikasi khusus untuk perairan dalam. Jenis ikan yang tertangkap di perairan selatan Jawa terdiri atas 337 spesies yang mewakili 99 famili, sedangkan di perairan barat Sumatera terdiri atas 215 spesies, mewakili 82 famili. Macrouridae salah satu famili yang memiliki kekayaan jenis terbanyak, menyusul famili lain Alepocephalidae, Ophidiidae, dan Myctophidae. Berdasarkan pada bobot total laju tangkap, komposisi jenis yang mendominansi di perairan selatan Jawa spesies Lamprogrammus niger (Ophidiidae) dan Plesiobatis sp.1 (Plesiobatididae-kerabat ikan pari). Sedangkan di barat Sumatera selain spesies Plesiobatis sp., spesies Diretmoides pauciradiatus dari famili Diretmidae juga mendominansi hasil total bobot hasil tangkapan di perairan ini. Sebaran laju tangkap secara horisontal yang tertinggi di selatan Jawa yang terkonsentrasi di sekitar perairan selatan Yogyakarta, sedangkan untuk kawasan barat Sumatera terkonsentrasi di sekitar perairan Banda Aceh sebelah barat dan perairan Pulau Enggano (Bengkulu). Sebaran laju tangkap secara vertikal cenderung menurun mulai dari kedalaman 200-900 m, namun pada kedalaman melebihi $900 \mathrm{~m}$, laju tangkap sangat tinggi.
\end{abstract}

KATAKUNCI: ikan laut dalam, sebaran laju tangkap, Samudera Hindia, selatan Jawa, barat Sumatera

\section{PENDAHULUAN}

Komoditas perikanan laut yang selama ini dikenal dan sering dikonsumsi sebagai makanan sehari-hari sebagian besar merupakan sumber daya perikanan laut dangkal yang ditangkap pada kedalaman kurang dari $200 \mathrm{~m}$, sedangkan ikan laut yang hidup pada kedalaman lebih dari $200 \mathrm{~m}$ yang dikenal dengan ikan laut dalam, belum banyak diketahui. Langka informasi tentang ikan laut dalam di Indonesia lebih disebabkan minimnya informasi tentang kegiatan penelitian dan kurangnya informasi yang dapat disebarkan secara luas, terutama informasi tentang usaha eksploitasi sangat terbatas.

Salah satu kegiatan penelitian yang diharapkan dapat memberikan kontribusi pengetahuan tentang jenis ikan laut dalam di perairan Indonesia dalam beberapa tahun terakhir hasil dari pengkajian yang dilakukan oleh Pusat Riset Perikanan Tangkap (Departemen Kelautan dan Perikanan) bekerjasama dengan Pemerintah Jepang (Overseas Fishery Cooperation Foundation) yang dilakukan di perairan zona ekonomi eksklusif Samudera Hindia pada tahun 2004 dan 2005.
Kegiatan ini menggunakan sarana K.R. Baruna Jaya IV (1.219 GT), yang dilengkapi dengan jaring pukat (trawl) yang dimodifikasi khusus untuk menangkap ikan pada kedalaman lebih dari $200 \mathrm{~m}$ serta perlengkapan penelitian oseanografi untuk memonitor kondisi lingkungan perairan. Daerah yang diobservasi meliputi perairan sebelah selatan Pulau Jawa mencakup daerah Cilacap (Jawa Tengah)-Prigi (Jawa Timur) dan perairan sebelah barat Pulau Sumatera meliputi Banda Aceh sampai Bengkulu.

Kegiatan penangkapan ikan dilakukan pada kedalaman sampai $1.500 \mathrm{~m}$ dengan lokasi stasiun dipilih secara acak sesuai dengan kontur dasar yang layak untuk pengoperasian jaring trawl. Ada 154 stasiun lokasi penangkapan, 102 antara lain di perairan selatan Jawa dan 52 stasiun lain di barat Sumatera telah diperoleh.

Pada tulisan ini akan diberikan sebagian informasi dari hasil penelitian tersebut yang mengungkapkan tentang jenis-jenis ikan yang tertangkap, komposisi hasil tangkapan, dan daerah sebaran. Informasi ini diharapkan dapat menambah wawasan pengetahuan tentang ikan laut dalam, untuk selanjutnya dapat 
digunakan sebagai salah satu data pendukung untuk mengkaji struktur komunitas dan kemungkinan pengembangan dalam upaya pemanfaatan sumber daya ikan laut dalam di perairan Indonesia.

\section{POPULASI IKAN YANG TERTANGKAP}

Biota laut dalam yang tertangkap dengan jaring pukat terdiri atas berbagai kelompok taksa yaitu populasi ikan, moluska, krustase, echinodermata, dan beberapa hewan invertebrata lain. Jenis ikan yang teridentifikasi berdasarkan pada kunci determinasi Nakabo (2002) terdiri atas 3 klas yaitu Myxini atau Agnatha (kelompok ikan tak berahang), klas Chondrichthyes (kelompok ikan bertulang rawan), dan klas Osteichthyes (kelompok ikan bertulang sejati) yang masing-masing wilayah perairan memiliki keragaman dan kelimpahan jenis yang bervariasi. Di perairan selatan Jawa tertangkap sekitar 337 spesies yang mewakili 99 famili, sedangkan di perairan barat Sumatera relatif lebih rendah terdiri atas 215 spesies, mewakili 82 famili (Lampiran 1 dan 2). Rendah jumlah spesies ikan yang tertangkap di perairan barat Sumatera kemungkinan berkaitan dengan sedikit jumlah stasiun penangkapan yang terjangkau oleh jaring trawl. Seperti diketahui bahwa hasil pemantauan dasar perairan menggunakan fish finder, sebagian besar wilayah perairan barat Sumatera yang diteliti memperlihatkan kedalaman lebih dari $2.000 \mathrm{~m}$, tidak mungkin terjangkau oleh jaring trawlyang mempunyai kemampuan beroperasi hanya sampai dengan kedalaman $1.500 \mathrm{~m}$, selain itu kontur dasar perairan juga banyak yang curam sehingga tidak layak untuk pengoperasian jaring trawl.

Berdasarkan pada komposisi jumlah spesies ikan yang tertangkap, menunjukkan bahwa famili Macrouridae mendominansi hasil tangkapan terbanyak. Fenomena yang sama juga dikatakan Iwamoto (1997) dalam Carpenter \& Niem (1999); Midalsky \& Fichter (1983) terhadap hasil penangkapan ikan laut dalam di sebelah barat Laut Pasifik dan pada sebagian besar perairan laut dalam di dunia.

Secara keseluruhan, hasil tangkapan ikan yang tergolong dalam famili Macrouridae memiliki kekayaan jenis terbanyak sekitar 35 spesies mewakili 11 marga, dibandingkan dengan hasil tangkapan yang dikatakan Gloerfelt \& Kailola (1984), di perairan antara sebelah selatan Indonesia sampai barat Laut Australia tampak relatif banyak sekitar 10 spesies, tetapi relatif sedikit dibandingkan hasil tangkapan di perairan sebelah barat Laut Pasifik seperti dikatakan Iwamoto (1997) dalam Carpenter \& Niem (1999), sekitar 94 spesies tergolong dalam 16 genera. Di wilayah lain, kelompok ikan Macrouridae ini memang selalu memperlihatkan jumlah kekayaan jenis paling banyak dalam struktur komunitas ikan laut dalam (Midalsky \& Fichter, 1983). Kelompok ikan lain berikut yang memperlihatkan kekayaan jenis terbanyak pada penelitian ini berturutturut famili Alepocephalidae (23 spesies dan 8 genera), Ophidiidae (19 spesies dan 9 genera), dan Myctophidae (13 spesies dan 8 genera).

Famili Macrouridae dikenal sebagai keluarga ikan grenadir atau rat tails, hampir semua anggota kerabat tidak memiliki sirip caudal tetapi memiliki sirip dorsal dan sirip analmenyatu ke arah ekor, meruncing tajam menyerupai ikan ekor tikus (Macrouridae). Bentuk kepala bervariasi mulai agak gepeng lonjong atau membulat dan membentuk moncong tajam ke arah depan, ukuran kepala tersebut relatif lebih besar dibandingkan tubuh, diameter mata ukuran relatif besar. Tubuh bersisik keras dan ditutupi cucuk kecil yang tajam Gloerfelt \& Kailola (1984); Frasser (1975); Iwamoto (1977) dalam Carpenter \& Niem (1999). Famili Macrouroidae termasuk famili ikan dengan jumlah spesies terbesar di laut dalam, daerah sebaran secara vertikal cukup luas terutama di daerah tropis yaitu mulai kedalaman 250-2.000 m, bahkan sampai dengan melebihi 5.000 m (Iwamoto, 1997 dalam Carpenter \& Niem (1999), sedangkan jumlah yang melimpah terkonsentrasi pada kedalaman $750 \mathrm{~m}$ (Midalsky \& Fichter, 1983), hidup selalu bergerombol dan menyukai habitat dekat dasar maupun berenang pada kolom air (wilayah bento pelagis). Pada penelitian ini, kerabat dari famili Macrouridae telah tertangkap mulai dari kedalaman 250-1.200 m, kelimpahan individu relatif tinggi dan kekayaan jenis yang paling banyak (8-10 spesies) diperoleh pada kedalaman antara 872-950 m. Gambar 1 memperlihatkan beberapa genera ikan laut dalam dari famili Macrouroidae.

Famili Alepocephalidae tertangkap pada kisaran kedalaman 350-1.200 m dengan jumlah 23 spesies mewakili 8 genera, sementara itu Sasonov \& Markle (1993) dalam Carpenter \& Niem (1999) menemukan sekitar 59 spesies tergolong dalam 20 genera di perairan sebelah barat Laut Pasifik. Kelompok famili Alepocephalidae pada umumnya menempati habitat sekitar dasar sampai kolom air (mid water) terutama menyukai pada kedalaman $708 \mathrm{~m}$, hidup selalu bergerombol (schooling) dengan jumlah tidak banyak (Midalsky \& Fichter, 1983). Morfologi tubuh menyerupai belut laut (kerondong atau moray) dengan ukuran bervariasi (panjang standar berkisar 15-50 cm), pada umumnya ikan ini tidak bersisik, kalaupun ada hanya di sebagian tubuh yang merupakan sisik cycloid yang lembut dan mudah terkelupas. Ukuran kepala relatif kecil (kurang dari 20\% dari panjang standar tubuh), memiliki sirip dorsal dan sirip anal yang 


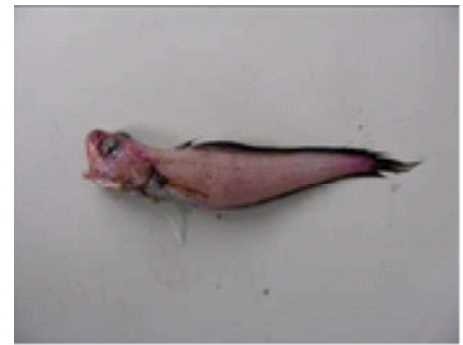

Bathygadus sp.

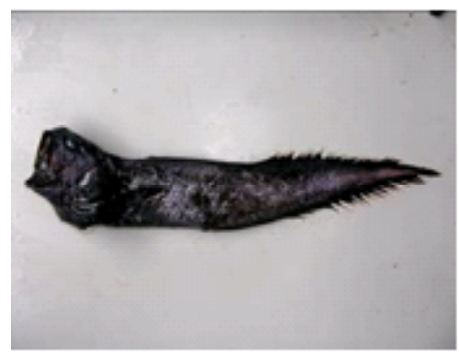

Monomitopus sp.

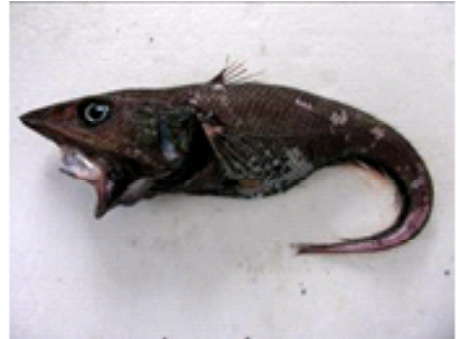

Caelorinchus sp.

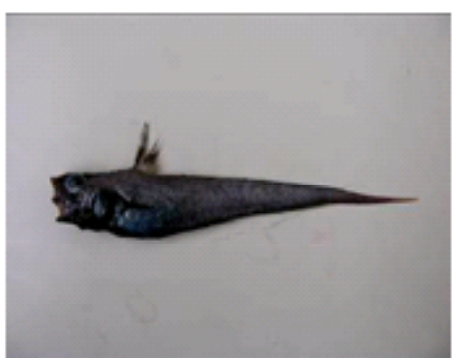

Nezumia sp.

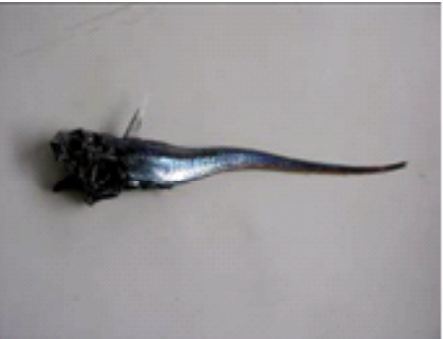

Hymenocephalus sp.

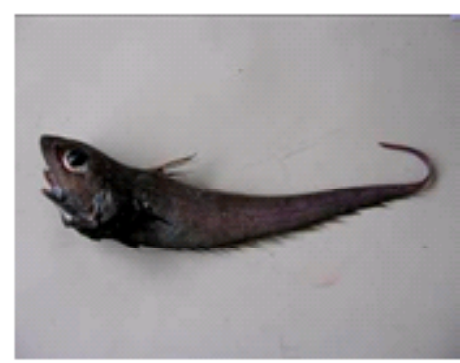

Ventrifossa sp.

Gambar 1. Beberapa genera ikan laut dalam dari famili Macrouridae yang tertangkap di peerairan zona ekonomi eksklusif Indonesia Samudera Hindia.

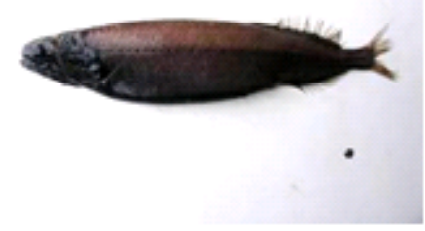

Alepocephalus sp.

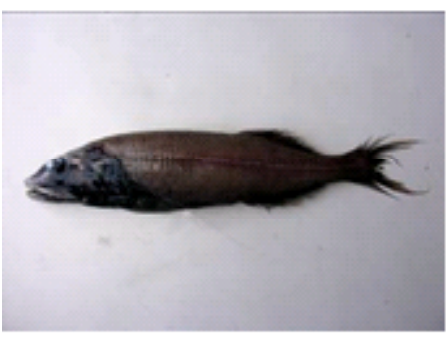

Narcetes sp.

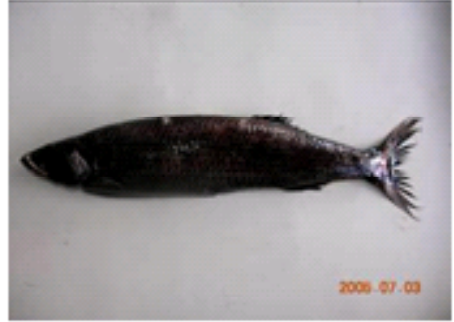

Bajacaliformia sp.

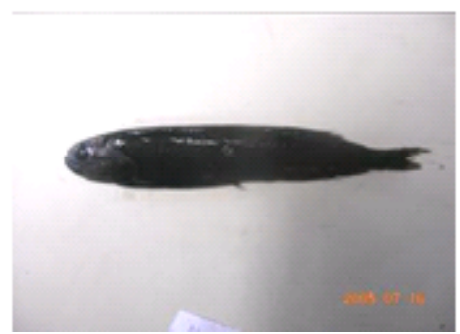

Xenodermichthys sp.

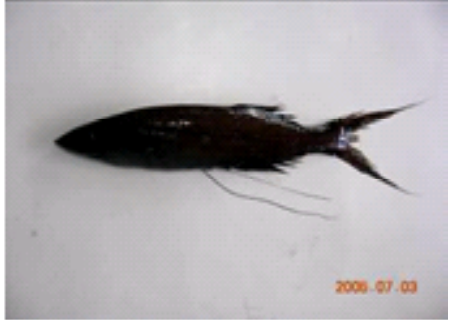

Talismania sp.

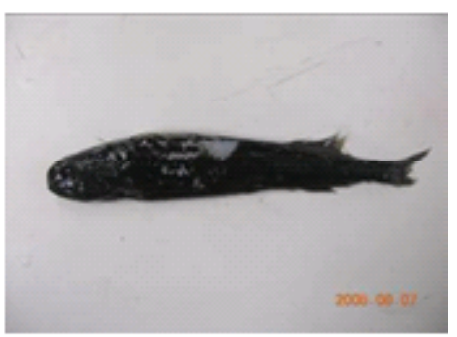

Rouleinasp.

Gambar 2. Beberapa genera ikan laut dalam dari famili Alepocephalidae yang tertangkap di perairan zona ekonomi eksklusif Indonesia Samudera Hindia.

terletak pada sepertiga bagian posterior tubuh. Corak tubuh menampakkan warna gelap, coklat, atau hitam. (Gloerfelt \& Kailola, 1984; Frasser, 1975; Sasonov \& Markle (1993) dalam Carpenter \& Niem, 1999). Beberapa genera ikan laut dalam dari famili Alepocephalidae dapat dilihat pada Gambar 2.
Famili Ophidiidae dikenal dengan brotula, cusk eel, atau sidat semu memiliki tubuh bersisik, bentuk tubuh agak memanjang dan berekor meruncing, panjang bervariasi mulai dari $10-100 \mathrm{~cm}$, memiliki sirip tunggal yang merupakan gabungan antara sirip punggung, sirip anal, dan sirip ekor, sedangkan sirip 
perut telah bermodifikasi menjadi sepasang jari mirip benang yang berfungsi untuk mencari makan. Warna dominan ikan ini kecoklatan, hidup di dasar perairan laut dalam dan mampu sampai kedalaman $8.730 \mathrm{~m}$. Di perairan sebelah barat Laut Pasifik ditemukan 63 spesies dengan 30 genera (Nielson, 1978 dalam Carpenter \& Niem (1999), di perairan antara sebelah selatan Indonesia sampai barat Laut Australia dikatakan Gloerfelt \& Kailola (1984) menemukan 14 spesies dan 8 genera, sedangkan pada penelitian tertangkap sekitar 19 spesies dan 9 genera. Beberapa genera dari famili Ophidiidae dapat dilihat pada Gambar 3.

Famili Myctopidae, dikenal sebagai ikan lentera (Lanternfishes), karena sebagian besar anggota kerabat memiliki organ cahaya (fotofor) pada sekujur tubuh dan menjadi salah satu karakter penting dalam identifikasi spesies. Jumlah spesies yang telah dikenal sekitar 250 spesies tergolong dalam 22 genera dan tersebar di Laut Artik sampai Antartik (Paxton \& Huley, 1986 dalam Carpenter \& Niem, 1999), sedangkan dalam penelitian ini ditemukan 13 spesies mewakili 8 genera. Ukuran tubuh pada umumnya relatif kecil (kurang dari $12 \mathrm{~cm}$ ) identik dengan ukuran jenis ikan teri yang banyak dijumpai di perairan laut dangkal, badan, kepala agak gepeng, mata relatif besar, dan berkembang dengan baik dibandingkan dengan jenis ikan laut dalam lain. Kelompok ikan ini hidup selalu bergerombol dan kelimpahan biomassa mendominansi $80 \%$ pada wilayah mesopelagis laut dalam, diprediksi memegang peranan penting dalam siklus rantai pakan (food chains) di laut dalam, karena sering melakukan migrasi vertikal ke lapisan di atas pada malam hari untuk mencari makan, kemudian pada siang hari menuju lapisan terdalam yang merupakan konsumsi penting bagi pemangsa organisme laut dalam. Warna tubuh agak bervariasi, tampak coklat atau hitam pada saat ikan ini berada di laut dalam, sedangkan pada saat berada pada perairan di lapisan di atas yang relatif dangkal (kurang dari $200 \mathrm{~m}$ ) ikan ini menampakkan sisik-sisik berwarna hijau metalik atau kebiruan (Gloerfelt \& Kailola (1984); Paxton \& Huley dalam Carpenter \& Niem (1999); Nybaken (1988). Beberapa genera dari famili ikan laut dalam dari famili Myctopidae dapat dilihat pada Gambar 4.

\section{KOMPOSISI JENIS IKAN}

Total bobot laju tangkap hasil tangkapan di perairan selatan Jawa diperoleh sekitar 11,329 ton, sedangkan di perairan barat Sumatera relatif lebih rendah 2,549 ton. Komposisi famili ikan yang tertangkap berdasarkan pada perbandingan terhadap total bobot hasil tangkapan tersebut diperoleh nilai yang bervariasi (Lampiran 3 dan 4). Tampak bahwa famili Ophidiidae dan Plesiobatididae di perairan selatan Jawa mendominansi 38 dan $23 \%$ dari total bobot hasil tangkapan. Spesies yang mendominansi Lamprogrammus niger (Ophidiidae) dan Plesiobatis sp.1 (Plesiobatididae). Famili Ophididae selain mendominansi dalam ukuran biomassa, kelimpahan individu juga mendominansi urutan kedua $(11,61 \%)$ setelah famili Myctopidae (52,14\%), sedangkan famili Plesiobathidae yang dikenal sebagai kerabat ikan pari (Plesiobatis sp.), walaupun biomassa mendominansi hasil tangkapan, tetapi kelimpahan jenis relatif sedikit

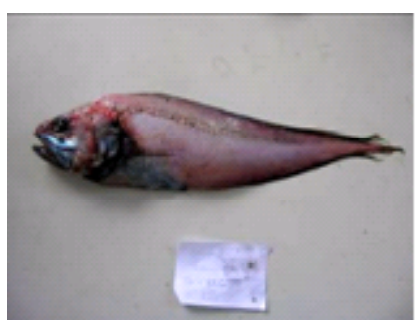

Homostolus sp.

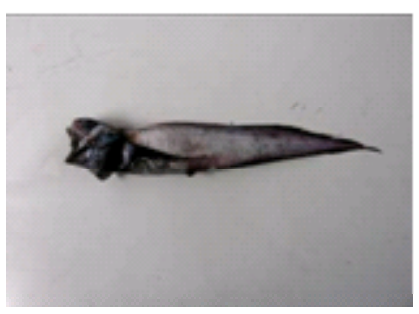

Dicrolene sp.

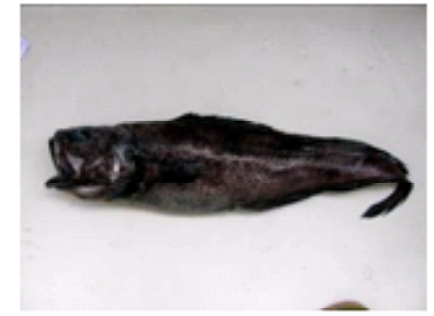

Neobythites sp.

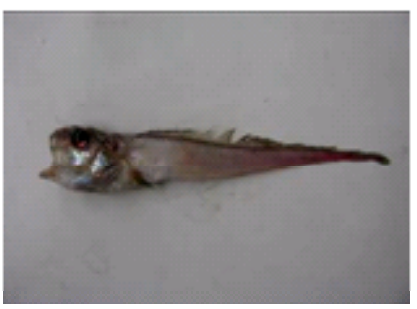

Glyptophidium sp.

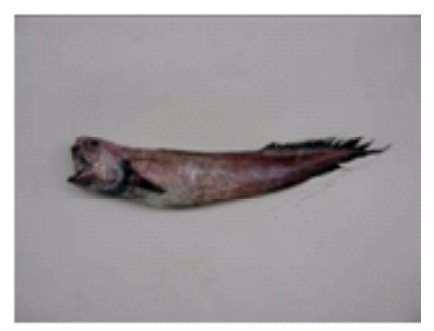

Monomitophus sp.

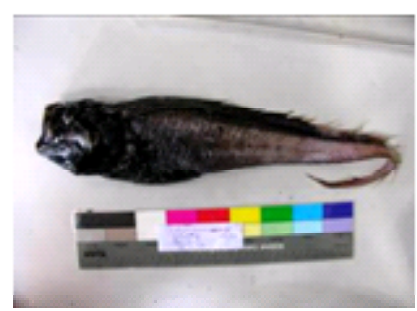

Lamprogrammus sp.

Gambar 3. Beberapa genera ikan laut dalam dari famili Ophidiidae yang tertangkap di perairan zona ekonomi eksklusif Indonesia Samudera Hindia. 


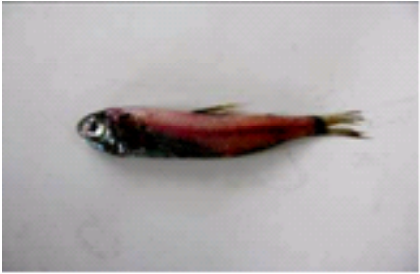

Benthosema sp.

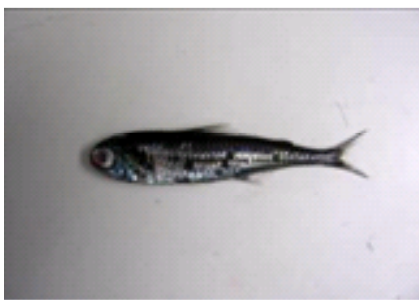

Myctopum sp.

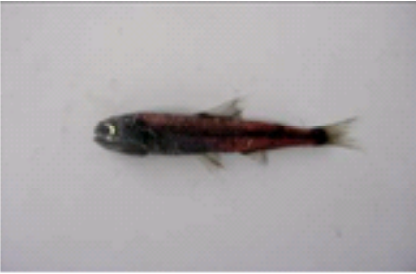

Diaphus sp.

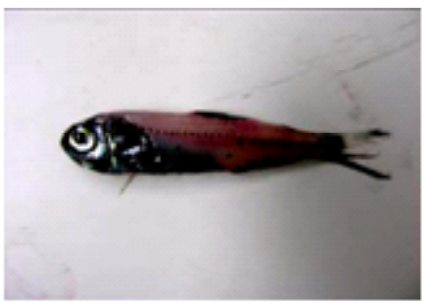

Diogonichthys sp.

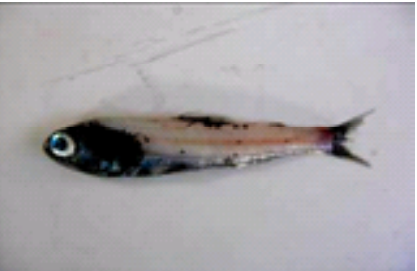

Lampadena sp.

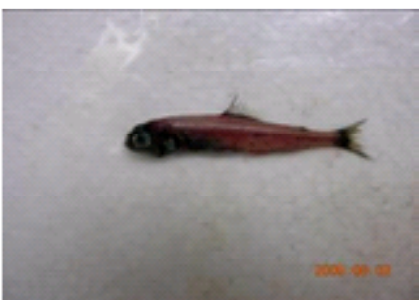

Symbolophorus sp.

Gambar 4. Beberapa genera ikan laut dalam dari famili Myctophidae yang tertangkap di perairan Samudera Hindia.

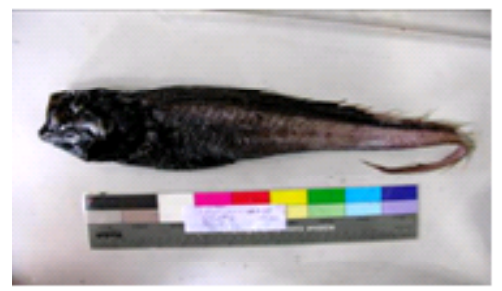

Lamprogrammus niger

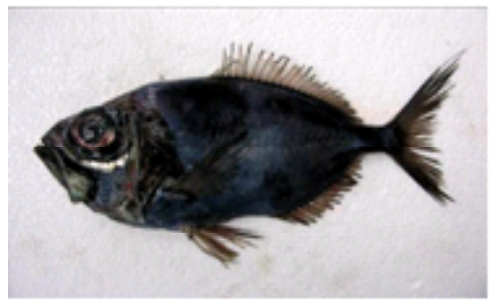

Diretmoides pauciradiatus

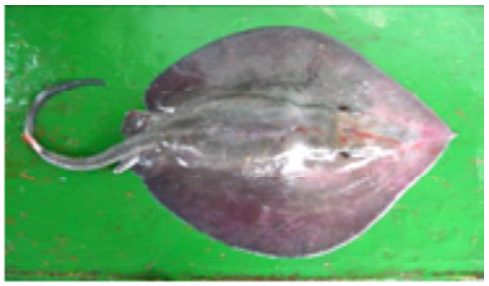

Plesiobatis sp.

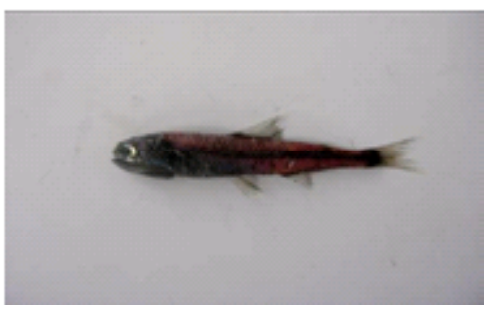

Diaphus sp.

Gambar 5. Beberapa spesies ikan laut dalam yang mendominansi hasil tangkapan di perairan zona ekonomi eksklusif Indonesia Samudera Hindia.

(mendominansi $0,17 \%$ ). Indikasi tersebut menunjukkan bahwa ukuran tubuh famili Plesiobathidae rata-rata relatif besar. Di perairan barat Sumatera famili Diretmidae mendominansi biomassa sekitar $13,8 \%$. Spesies dari kelompok ini yang dominan Diretmoides pauciradiatus. Famili lain yang tampak mendominansi Plesiobatididae (13,5\%) yang banyak diwakili oleh spesies ikan pari.

Selain mendominansi dari segi biomassa, famili Diretmidae juga mendominansi dalam kelimpahan individu (11,5\%). Famili lain yang juga tampak mendominansi Myctopidae (22,5\%) dan Ostracoberycidae $(14,2 \%)$, sebaliknya famili
Plesiobatididae jumlah individu relatif sedikit (mendominansi 0,08\%). Beberapa jenis ikan laut dalam yang mendominansi hasil tangkapan dapat dilihat pada Gambar 5 .

\section{DISTRIBUSI LAJU TANGKAP}

\section{Distribusi Horisontal}

Variasi laju tangkap ikan yang diperoleh pada setiap stasiun penangkapan di perairan selatan Jawa berkisar 8,72-2.075,67 kg (Gambar 6). Laju tangkap tertinggi ditemukan pada lokasi stasiun 26 (sekitar perairan selatan Yogyakarta), di mana $70 \%$ 
didominansi oleh jenis ikan Lamprogrammus niger, sebaliknya laju tangkap terendah ditemukan pada stasiun 48 (sekitar perairan selatan Tulung Agung) yang didominansi jenis ikan Diaphus sp.1 (41\%).

Di perairan barat Sumatera, laju tangkap berkisar 3,02-330,04 kg. Laju tangkap tertinggi terpusat di barat Banda Aceh dan sekitar Pulau Enggano (Bengkulu) (Gambar 7).

\section{Distribusi vertikal}

Berdasarkan pada pengelompokkan strata kedalaman perairan yang masing-masing berselang
$100 \mathrm{~m}$, mulai dari kedalaman $200 \mathrm{~m}$ sampai lebih dari $900 \mathrm{~m}$, diperoleh diagram variasi nilai rata-rata laju tangkap ikan pada setiap strata kedalaman (Gambar 8). Laju tangkap cenderung menurun seiring bertambah kedalaman sampai kedalaman $900 \mathrm{~m}$, tetapi pada kedalaman lebih dari $900 \mathrm{~m}$, diperoleh laju tangkap sangat tinggi. Jenis ikan yang mendominansi pada kedalaman ini Lamprogrammus niger (Ophidiidae) dengan total tangkapan 3,5 ton (90\% dari total laju tangkap pada strata kedalaman lebih dari $900 \mathrm{~m}$ ).

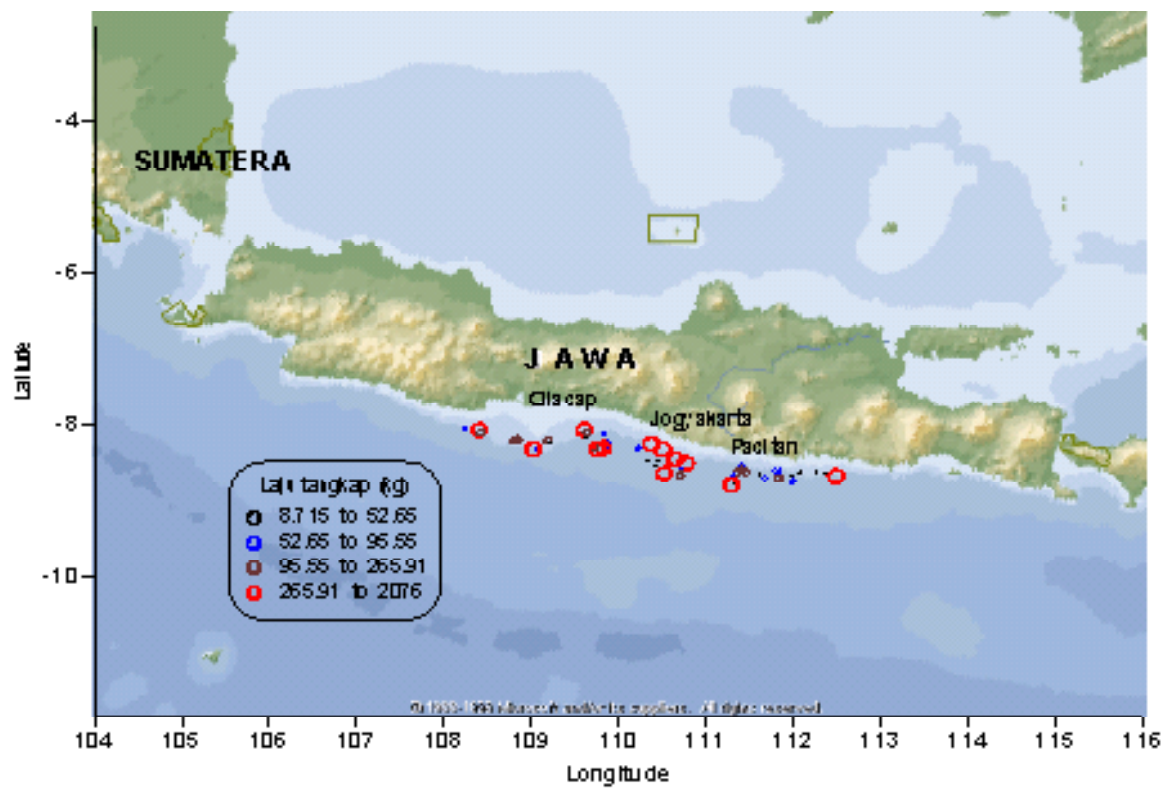

Gambar 6. Pola sebaran laju tangkap ikan laut dalam secara horisontal diperairan selatan Jawa.

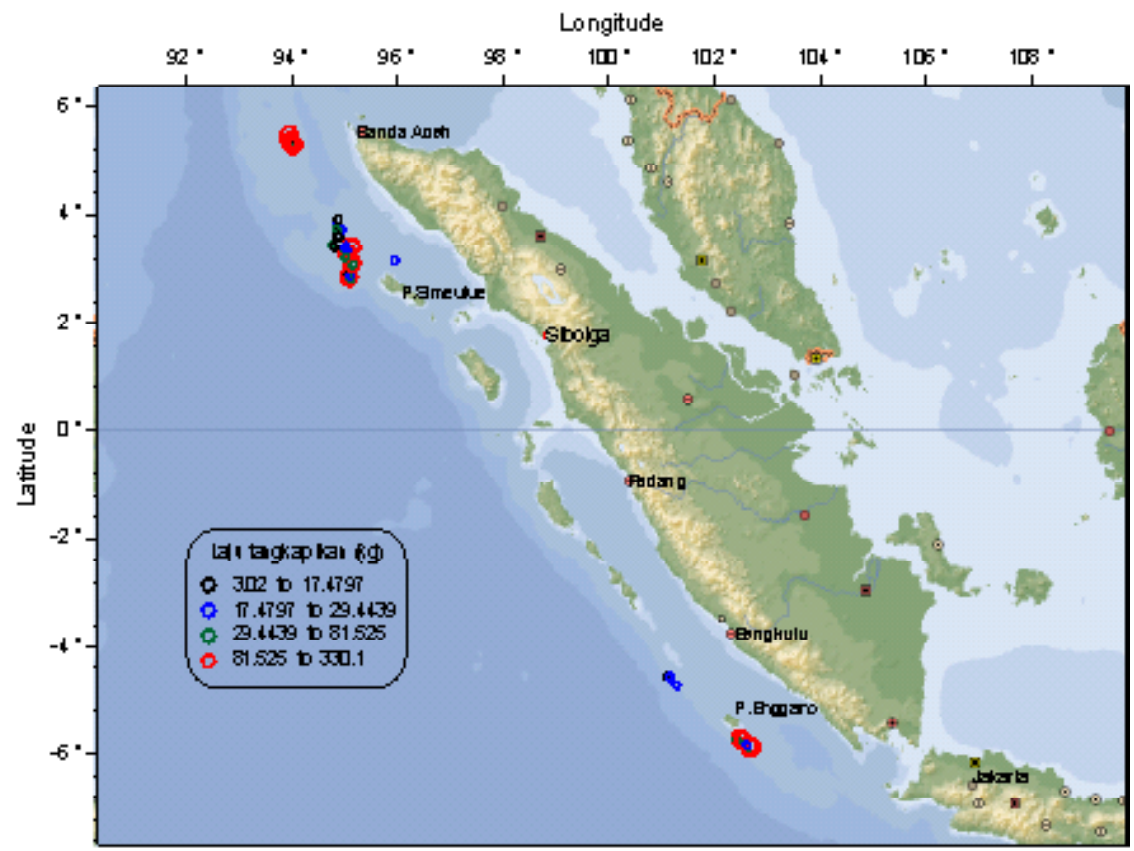

Gambar 7. Pola sebaran laju tangkap ikan laut dalam secara horisontal di perairan barat Sumatera. 


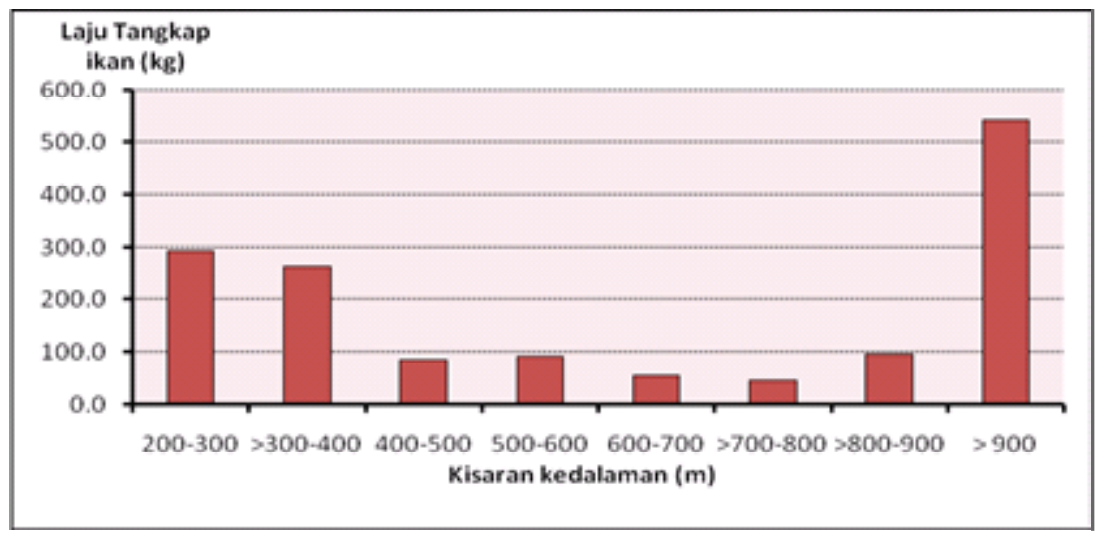

Gambar 8. Sebaran laju tangkap ikan laut dalam pada strata kedalaman di perairan zona ekonomi eksklusif Indonesia Samudera Hindia.

\section{KESIMPULAN}

Jenis ikan laut dalam yang tertangkap di perairan zona ekonomi eksklusif Indonesia Samudera Hindia (barat Sumatera dan selatan Jawa) sekitar 416 spesies, mewakili 111 famili, di mana famili Macrouridae memiliki kekayaan jenis terbanyak. Jenis ikan yang mendominansi bobot hasil tangkapan Lamprogrammus niger (Ophidiidae), Plesiobatis sp. (Plesiobatididae), dan Diretmoides pauciradiatus (Diretmidae). Sebaran kepadatan ikan laut dalam secara horisontal paling banyak terkonsentrasi di sekitar perairan sebelah selatan Yogyakarta, sebelah barat Banda Aceh dan sekitar Bengkulu, sedangkan secara vertikal, kepadatan relatif tinggi ditemukan pada kedalaman 200-400 m, kemudian kepadatan cenderung menurun seiring dengan bertambah kedalaman sampai $900 \mathrm{~m}$, namun kepadatan meningkat sangat tinggi pada kedalaman lebih dari $900 \mathrm{~m}$.

\section{PERSANTUNAN}

Kegiatan dari hasil riset pengkajian sumber daya ikan laut dalam di perairan zona ekonomi eksklusif Indonesia Samudera Hindia, T. A. 2005, kerja sama antara Indonesia (Pusat Riset Perikanan Tangkap(Badan Riset Kelautan dan Perikanan-Departemen Kelautan dan Perikanan dan Jepang (Overseas Fishery Cooperation Foundation).

\section{DAFTAR PUSTAKA}

Carpenter, K. E. \& Niem V. H. (eds). 1999. F. A. O. Species Identification Guide for Fishery Purposes. The Living Marine Resources of the Western Central Pasific. Vol.3. Batoid Fishes, Chimaeras, and Bony Fishes. Part 1 (Elopidae to Linophrynidae). Rome. 406 pp.

Frasser, H. T. 1975. Fishes of the World An Illustrated Dictionary. First American Edition. Macmillan Publishing Co. Inc. New York.

Gloerfelt, T. T. \& P. J. Kailola. 1984. Trawled Fishes of Southern Indonesia and Northern Australia. The Directorate General of Fisheries. Indonesia. 406 pp.

Midalsky, E. C. \& G. S. Fichter. 1983. The Fresh and Salt Water Fishes of the World. Greenwich House. Crown Publishers. Inc. New York.

Nakabo, T. 2002. Fishes of Japan with Pictoralkeys to the Species. English Edition I and II. Tokay University. Press. Tokyo. 1.749 pp.

Nybaken, J. W. 1988. Biologi Laut: Suatu Pendekatan Ekologis. Alih Bahasa M. Eidman et al. Cetakan 1. Gramedia. 480 pp. 
Lampiran 1. Jumlah spesies dan famili ikan laut dalam yang tertangkap di perairan selatan Jawa

\begin{tabular}{|c|c|c|c|c|c|}
\hline No. & Famili & Jumlah spesies & No. & Famili & Jumlah spesies \\
\hline 1. & Myxinidae & 1 & 51. & Chaunacidae & 5 \\
\hline 2. & Chimaeridae & 4 & 52. & Ogcocephalidae & 9 \\
\hline 3. & Alopiidae & 1 & 53. & Oneirodidae & 3 \\
\hline 4. & Scyliorhinidae & 3 & 54. & Diceratiidae & 2 \\
\hline 5. & Triakidae & 2 & 55. & Himantolophidae & 3 \\
\hline 6. & Carcharhinidae & 1 & 56. & Melamphaidae & 2 \\
\hline 7. & Etmopteridae & 1 & 57. & Rondeletiidae & 1 \\
\hline 8. & Centrophoridae & 4 & 58. & Barbourisiidae & 1 \\
\hline 9. & Squalidae & 3 & 59. & Centomimidae & 1 \\
\hline 10. & Squatinidae & 1 & 60. & Hispidoberycidae & 1 \\
\hline 11. & Torpedinidae & 1 & 61. & Berycidae & 1 \\
\hline 12. & Rajidae & 8 & 62. & Trachichthyidae & 3 \\
\hline 13. & Plesiobatididae & 3 & 63. & Diretmidae & 2 \\
\hline 14. & Halosauridae & 1 & 64. & Anoplogastridae & 1 \\
\hline 15. & Notacanthidae & 5 & 65. & Macrurocyttidae & 2 \\
\hline 16. & Colocongridae & 2 & 66. & Zeidae & 3 \\
\hline 17. & Congridae & 6 & 67. & Grammicolepididae & 3 \\
\hline 18. & Muraenesocidae & 2 & 68. & Caproidae & 4 \\
\hline 19. & Derichthyidae & 1 & 69. & Scorpaenidae & 4 \\
\hline 20. & Nemichthyidae & 3 & 70. & Triglidae & 4 \\
\hline 21. & Serrivomeridae & 1 & 71. & Peristediidae & 8 \\
\hline 22. & Nettastomatidae & 6 & 72. & Hoplichthyidae & 1 \\
\hline 23. & Microstomatidae & 2 & 73. & Liparidae & 1 \\
\hline 24. & Alepocephalidae & 23 & 74. & Psychrolutidae & 1 \\
\hline 25. & Gonostomatidae & 5 & 75. & Acropomatidae & 7 \\
\hline 26. & Sternoptychidae & 5 & 76. & Howellidae & 3 \\
\hline 27. & Phosichthyidae & 5 & 77. & Ostracoberycidae & 1 \\
\hline 28. & Chauliodontidae & 2 & 78. & Symphysanodontidae & 1 \\
\hline 29. & Stomiidae & 2 & 79. & Priacanthidae & 1 \\
\hline 30. & Asteronesthidae & 3 & 80. & Epigonidae & 3 \\
\hline 31. & Melanostomiidae & 4 & 81. & Nemipteridae & 2 \\
\hline 32. & Malacosteidae & 3 & 82. & Sciaenidae & 1 \\
\hline 33. & Idiacanthidae & 1 & 83. & Bathyclupeidae & 1 \\
\hline 34. & Ateleopodidae & 1 & 84. & Cepolidae & 2 \\
\hline 35. & Synodontidae & 1 & 85. & Centrolophidae & 2 \\
\hline 36. & Ipnopidae & 2 & 86. & Nomeidae & 6 \\
\hline 37. & Chlorophthalmidae & 3 & 87. & Percophidae & 3 \\
\hline 38. & Alepisauridae & 1 & 88. & Chiasmodontidae & 1 \\
\hline 39. & Paralepididae & 4 & 89. & Uranoscopidae & 2 \\
\hline 40. & Scopelarchidae & 1 & 90. & Gobiidae & 1 \\
\hline & Bathysauridae & 1 & 91. & Scombrolabracidae & 1 \\
\hline & Neoscopelidae & 5 & 92. & Gempylidae & 6 \\
\hline 43. & Myctophidae & 13 & 93. & Trichiuridae & 5 \\
\hline 44. & Polymixiidae & 2 & 94. & Bothidae & 1 \\
\hline 45. & Melanonidae & 2 & 95. & Pleuronectidae & 1 \\
\hline & Bregmacerotidae & 1 & 96. & Poecilopsettidae & 1 \\
\hline 47. & Macrouridae & 33 & 97. & Cynoglossidae & 3 \\
\hline & Macrouroididae & 1 & 98. & Triacanthodidae & 8 \\
\hline & Ophidiidae & 19 & 99. & Unidentified fish & 1 \\
\hline 50. & Lophiidae & 2 & & Jumlah spesies & 337 \\
\hline
\end{tabular}


Jenis Ikan Laut Dalam yang Tertangkap di ..... Samudera Hindia (Suprapto dan Sunarno, M.T.D.)

Lampiran 2. Jumlah spesies dan famili ikan laut dalam yang tertangkap di perairan barat Sumatera

\begin{tabular}{|c|c|c|c|c|}
\hline No. & $\begin{array}{l}\text { Famili } \\
\end{array}$ & Jumlah spesies & No. $\quad$ Famili & Jumlah spesies \\
\hline & Chimaeridae & 3 & 42. Myctophidae & 10 \\
\hline & Rhinochimaeridae & 2 & 43. Polymixiidae & 1 \\
\hline & Mitsukurinidae & 1 & 44. Moridae & 3 \\
\hline & Scyliorhinidae & 2 & 45. Melanonidae & 1 \\
\hline & Hexanclidae & 1 & 46. Macrouridae & 16 \\
\hline & Etmopteridae & 1 & 47. Macrouroididae & 1 \\
\hline & Somniosidae & 1 & 48. Ophidiidae & 11 \\
\hline & Centrophoridae & 3 & 49. Lophiidae & 2 \\
\hline & Squalidae & 2 & 50. Chaunacidae & 1 \\
\hline 10. & Squatinidae & 1 & 51. Ogcocephalidae & 2 \\
\hline 11. & Torpedinidae & 1 & 52. Oneirodidae & 2 \\
\hline 12. & Rajidae & 3 & 53. Diceratiidae & 1 \\
\hline & Plesiobatididae & 3 & 54. Himantolophidae & 1 \\
\hline 14. & Halosauridae & 1 & 55. Melamphaidae & 5 \\
\hline 15. & Notacanthidae & 5 & 56. Barbourisiidae & 1 \\
\hline 16. & Colocongridae & 1 & 57. Hispidoberycidae & 1 \\
\hline 17. & Congridae & 4 & 58. Berycidae & 1 \\
\hline 18. & Muraenesocidae & 3 & 59. Trachichthyidae & 2 \\
\hline 19. & Derichthyidae & 1 & 60. Diretmidae & 2 \\
\hline 20. & Nemichthyidae & 3 & 61. Anoplogastridae & 1 \\
\hline 21. & Serrivomeridae & 1 & 62. Zeidae & 5 \\
\hline 22. & Nettastomatidae & 2 & 63. Grammicolepididae & 2 \\
\hline 23. & Microstomatidae & 2 & 64. Caproidae & 3 \\
\hline 24. & Alepocephalidae & 11 & 65. Scorpaenidae & 3 \\
\hline 25. & Gonostomatidae & 3 & 66. Triglidae & 1 \\
\hline 26. & Sternoptychidae & 4 & 67. Peristediidae & 5 \\
\hline 27. & Phosichthyidae & 1 & 68. Acropomatidae & 1 \\
\hline 28. & Chauliodontidae & 1 & 69. Ostracoberycidae & 1 \\
\hline 29. & Stomiidae & 1 & 70. Serranidae & 1 \\
\hline 30. & Asteronesthidae & 6 & 71. Epigonidae & 1 \\
\hline 31. & Melanostomiidae & 6 & 72. Bathyclupeidae & 1 \\
\hline 32. & Malacosteidae & 2 & 73. Centrolophidae & 1 \\
\hline 33. & Idiacanthidae & 1 & 74. Nomeidae & 2 \\
\hline 34. & Ateleopodidae & 1 & 75. Percophidae & 1 \\
\hline 35. & Ipnopidae & 2 & 76. Chiasmodontidae & 3 \\
\hline 36. & Notosudidae & 2 & 77. Scombrolabracidae & 1 \\
\hline 37. & Chlorophthalmidae & 3 & 78. Xiphiidae & 1 \\
\hline 38. & Alepisauridae & 1 & 79. Gempylidae & 7 \\
\hline 39. & Paralepididae & 4 & 80. Trichiuridae & 2 \\
\hline 40. & Scopelarchidae & 1 & 81. Bothidae & 1 \\
\hline \multirow{2}{*}{\multicolumn{2}{|c|}{ 41. Neoscopelidae }} & 4 & 82. Triacanthodidae & 6 \\
\hline & & & Jumlah spesies & 215 \\
\hline
\end{tabular}


Lampiran 3. Komposisi laju tangkap famil ikan laut dalam di perairan selatan Jawa

\begin{tabular}{|c|c|c|c|c|c|c|c|}
\hline No. & Famili & kg & $\%$ & No. & Famili & kg & $\%$ \\
\hline 1. & Acropomatidae & 700.520 & 6.183 & 43. & Melanostomiidae & 0,227 & 0,002 \\
\hline 2. & Alepocephalidae & 167.164 & 1.475 & 44. & Microstomatidae & 2.020 & 0,018 \\
\hline 3. & Alopiidae & 20.900 & 0,184 & 45. & Muraenesocidae & 0,620 & 0,005 \\
\hline 4. & Anoplogastridae & 0,065 & 0,001 & 46. & Myctophidae & 624.581 & 5.513 \\
\hline 5. & Asteronesthidae & 0,427 & 0,004 & 47. & Myxinidae & 0,140 & 0,001 \\
\hline 6. & Ateleopodidae & 1.220 & 0,011 & 48. & Nemichthyidae & 0,334 & 0,003 \\
\hline 7. & Barbourisiidae & 0,985 & 0,009 & 49. & Nemipteridae & 0,475 & 0,004 \\
\hline 8. & Bathyclupeidae & 62.435 & 0,551 & 50. & Neoscopelidae & 33.200 & 0,293 \\
\hline 9. & Bathysauridae & 0,105 & 0,001 & 51. & Nettastomatidae & 21.725 & 0,192 \\
\hline 10. & Berycidae & 12.340 & 0,101 & 52. & Nomeidae & 71.130 & 0,628 \\
\hline 11. & Bothidae & 0,335 & 0,003 & 53. & Notacanthidae & 21.215 & 0,187 \\
\hline 12. & Caproidae & 5.570 & 0,049 & 54. & Ogcocephalidae & 2.580 & 0,023 \\
\hline 13. & Carcharhinidae & 9.500 & 0,084 & 55. & Oneirodidae & 2.165 & 0,019 \\
\hline 14. & Centrolophidae & 28.055 & 0,248 & 56. & Ophidiidae & 4.336.121 & 38.274 \\
\hline 15. & Centrophoridae & 258.090 & 2.278 & 57. & Ostracoberycidae & 0,190 & 0,002 \\
\hline 16. & Cepolidae & 0,075 & 0,001 & 58. & Paralepididae & 0,782 & 0,007 \\
\hline 17. & Chauliodontidae & 0,365 & 0,003 & 59. & Percophidae & 2.500 & 0,022 \\
\hline 18. & Chaunacidae & 7.294 & 0,064 & 60. & Peristediidae & 62.585 & 0,552 \\
\hline 19. & Chiasmodontidae & 0,085 & 0,001 & 61. & Phosichthyidae & 0,295 & 0,003 \\
\hline 20. & Chimaeridae & 351.445 & 3.102 & 62. & Plesiobatididae & 2.611 .395 & 23.050 \\
\hline 21. & Chlorophthalmidae & 36.259 & 0,320 & 63. & Polymixiidae & 13.750 & 0,121 \\
\hline 22. & Colocongridae & 55.725 & 0,492 & 64. & Priacanthidae & 1.580 & 0,014 \\
\hline 23. & Congridae & 64.415 & 0,569 & 65. & Psychrolutidae & 1.915 & 0,017 \\
\hline 24. & Cynoglossidae & 0,5234 & 0,005 & 66. & Rajidae & 222.175 & 1.961 \\
\hline 25. & Derichthyidae & 0,250 & 0,002 & 67. & Sciaenidae & 0,335 & 0,003 \\
\hline 26. & Diceratiidae & 0,730 & 0,006 & 68. & Scombrolabracidae & 0,120 & 0,001 \\
\hline 27. & Diretmidae & 0,890 & 0,008 & 69. & Scorpaenidae & 3.084 & 0,027 \\
\hline 28. & Epigonidae & 86.675 & 0,077 & 70. & Scyliorhinidae & 12.290 & 0,108 \\
\hline 29. & Etmopteridae & 0,065 & 0,001 & 71. & Serrivomeridae & 0,205 & 0,002 \\
\hline 30. & Gempylidae & 42.395 & 0,374 & 72. & Squalidae & 58.165 & 0,513 \\
\hline 31. & Grammicolepididae & 3.575 .000 & 0,032 & 73. & Squatinidae & 68.740 & 0,607 \\
\hline 32. & Halosauridae & 24.445 & 0,022 & 74. & Sternoptychidae & 0,132 & 0,001 \\
\hline 33. & Himantolophidae & 0,320 & 0,003 & 75. & Synodontidae & 42.540 & 0,375 \\
\hline 34. & Hoplichthyidae & 0,300 & 0,003 & 76. & Torpedinidae & 7.175 & 0,063 \\
\hline 35. & Idiacanthidae & 0,095 & 0,001 & 77. & Trachichthyidae & 6.311 & 0,056 \\
\hline 36. & Ipnopidae & 8.655 & 0,076 & 78. & Triacanthodidae & 6.848 & 0,060 \\
\hline 37. & Liparidae & 0,100 & 0,001 & 79. & Triakidae & 1.360 & 0,012 \\
\hline 38. & Lophiidae & 27.230 & 0,240 & 80. & Trichiuridae & 642.260 & 5.669 \\
\hline 39. & Macrouridae & 514.621 & 45.420 & 81. & Triglidae & 2.875 & 0,025 \\
\hline 40. & Macrouroididae & 25.875 & 0,228 & 82. & Uranoscopidae & 6.495 & 0,057 \\
\hline 41. & Malacosteidae & 0,175 & 0,002 & 83. & Zeidae & 13.559 & 0,120 \\
\hline 42. & Melanonidae & 2.140 & 0,019 & & Total & $11.328,62$ & \\
\hline
\end{tabular}


Jenis Ikan Laut Dalam yang Tertangkap di .... Samudera Hindia (Suprapto dan Sunarno, M.T.D.)

Lampiran 4. Komposisi laju tangkap famil ikan laut dalam di perairan barat Sumatera

\begin{tabular}{|c|c|c|c|c|c|c|c|}
\hline No. & Famili & kg & $\%$ & No. & Famili & kg & $\%$ \\
\hline 1. & Acropomatidae & 7.355 & 0,289 & 42. & Microstomatidae & 1.739 & 0,068 \\
\hline 2. & Alepisauridae & 0,120 & 0,005 & 43. & Mitsukurinidae & 150.000 & 5.884 \\
\hline 3. & Alepocephalidae & 94.849 & 3.721 & 44. & Moridae & 5.955 & 0,234 \\
\hline 4. & Anoplogastridae & 0,155 & 0,006 & 45. & Muraenesocidae & 15.265 & 0,599 \\
\hline 5. & Asteronesthidae & 1.881 & 0,074 & 46. & Myctophidae & 51.225 & 2.009 \\
\hline 6. & Ateleopodidae & 5.245 & 0,206 & 47. & Nemichthyidae & 1.996 & 0,078 \\
\hline 7. & Barbourisiidae & 3.350 & 0,131 & 48. & Neoscopelidae & 32.843 & 1.288 \\
\hline 8. & Bathyclupeidae & 0,990 & 0,039 & 49. & Nettastomatidae & 37.150 & 1.457 \\
\hline 9. & Berycidae & 129.050 & 5.062 & 50. & Nomeidae & 1.740 & 0,068 \\
\hline 10. & Bothidae & 0,115 & 0,005 & 51. & Notacanthidae & 7.450 & 0,292 \\
\hline 11. & Caproidae & 1.205 & 0,047 & 52. & Notosudidae & 0,135 & 0,005 \\
\hline 12. & Centrolophidae & 0,040 & 0,002 & 53. & Ogcocephalidae & 0,335 & 0,013 \\
\hline 13. & Centrophoridae & 115.595 & 4.535 & 54. & Oneirodidae & 0,721 & 0,028 \\
\hline 14. & Chauliodontidae & 0,884 & 0,035 & 55. & Ophidiidae & 87.135 & 3.418 \\
\hline 15. & Chaunacidae & 0,575 & 0,023 & 56. & Ostracoberycidae & 212.874 & 8.351 \\
\hline 16. & Chiasmodontidae & 0,280 & 0,011 & 57. & Paralepididae & 16.214 & 0,636 \\
\hline 17. & Chimaeridae & 14.725 & 0,578 & 58. & Percophidae & 0,060 & 0,002 \\
\hline 18. & Chlorophthalmidae & 11.270 & 0,442 & 59. & Peristediidae & 2.075 & 0,081 \\
\hline 19. & Colocongridae & 10.760 & 0,422 & 60. & Phosichthyidae & 3.490 & 0,137 \\
\hline 20. & Congridae & 13.400 & 0,526 & 61. & Plesiobatididae & 343.120 & 13.460 \\
\hline 21. & Derichthyidae & 0,130 & 0,005 & 62. & Polymixiidae & 7.815 & 0,307 \\
\hline 22. & Diceratiidae & 0,490 & 0,019 & 63. & Rajidae & 12.105 & 0,475 \\
\hline 23. & Diretmidae & 351.620 & 13.794 & 64. & Rhinochimaeridae & 7.265 & 0,285 \\
\hline 24. & Epigonidae & 0,340 & 0,013 & 65. & Scombrolabracidae & 0,135 & 0,005 \\
\hline 25. & Etmopteridae & 0,440 & 0,017 & 66. & Scopelarchidae & 0,095 & 0,004 \\
\hline 26. & Gempylidae & 12.005 & 0,471 & 67. & Scorpaenidae & 102.772 & 4.032 \\
\hline 27. & Gonostomatidae & 0,467 & 0,018 & 68. & Scyliorhinidae & 5.820 & 0,228 \\
\hline 28. & Grammicolepididae & 25.682 & 1.007 & 69. & Serranidae & 0,220 & 0,009 \\
\hline 29. & Halosauridae & 2.507 & 0,098 & 70. & Serrivomeridae & 0,367 & 0,014 \\
\hline 30. & Hexanclidae & 1.025 & 0,040 & 71. & Somniosidae & 2.320 & 0,091 \\
\hline 31. & Himantolophidae & 0,015 & 0,001 & 72. & Squalidae & 3.675 & 0,144 \\
\hline 32. & Hispidoberycidae & 1.215 & 0,048 & 73. & Squatinidae & 8.500 & 0,333 \\
\hline 33. & Idiacanthidae & 0,014 & 0,001 & 74. & Sternoptychidae & 0,243 & 0,010 \\
\hline 34. & Ipnopidae & 3.475 & 0,136 & 75. & Stomiidae & 0,164 & 0,006 \\
\hline 35. & Lophiidae & 17.695 & 0,694 & 76. & Torpedinidae & 11.800 & 0,463 \\
\hline 36. & Macrouridae & 241.083 & 9.457 & 77. & Trachichthyidae & 255.387 & 10.019 \\
\hline 37. & Macrouroididae & 21.115 & 0,828 & 78. & Triacanthodidae & 4.460 & 0,175 \\
\hline 38. & Malacosteidae & 0,218 & 0,009 & 79. & Trichiuridae & 16.215 & 0,636 \\
\hline 39. & Melamphaidae & 0,298 & 0,012 & 80. & Triglidae & 0,130 & 0,005 \\
\hline 40. & Melanonidae & 28.550 & 1.120 & 81. & Xiphiidae & 5.900 & 0,231 \\
\hline \multirow[t]{2}{*}{41.} & Melanostomiidae & 0,925 & 0,036 & 82. & Zeidae & 11.090 & 0,435 \\
\hline & & & & & Total & 2.549 .000 & \\
\hline
\end{tabular}

